\title{
Biologists under control
}

\author{
Sheldon Krimsky
}

The Politics of Uncertainty: Regulating Recombinant DNA Research in Britain.

By David Bennett, Peter Glasner and David Travis.

Routledge \& Kegan Paul: 1986. Pp.218. £20, \$35.

Cloning and the Constitution: An Inquiry into Governmental Policymaking and

Genetic Experimentation. By Ira H. Carmen.

University of Wisconsin Press: 1986. Pp.223. \$22.50, £27.

IN February 1986, eleven years to the month after the international meeting on the risks of recombinant DNA (rDNA) research was convened at Asilomar in Monterey, California, citizens of that county stopped the first federally authorized field test of a genetically modified bacterium. The California biotechnology company Advanced Genetic Sciences had received approval from the US Environmental Protection Agency and the National Institutes of Health (NIH) to spray the bacterium on a strawberry patch as a means of assessing its potential for inhibiting ice-nucleation. Local residents successfully opposed the release on the grounds that the risks were unknown and that no effort had been made to inform the community.

What a strange coincidence! "Asilomar 1975 " was the starting point of the first generation of debates on the safety and regulation of rDNA technology. Now, as the technology reaches the stage of agricultural use, a new public controversy has emerged at the same place. This time the issue is over the intentional release of genetically engineered products into the biosphere.

Science and politics are still playing out the legacy of "Asilomar 1975" as gene splicing takes new turns in its journey towards public acceptance. No event since the release of thermonuclear energy, in the form of the atomic bomb, has fostered such intense discussion about the responsibility and accountability of science to society. The questions are twofold. If faced with uncertainties about the safety of their research, will scientists ever again expose their collective anxieties to the public; that is, has Asilomar and its aftermath driven scientists into a shell? And what has the experience of the rDNA controversy taught us about science and democracy?

The two books reviewed here provide a fresh set of perspectives on these matters. The Politics of Uncertainty is the first book-length investigation of British policy on rDNA research; cast in a sociological framework, it is rich in historical detail and filled with insightful comparisons of British and American policy-making. Cloning and the Constitution examines ielected periods of the rDNA debate in the United States through the prism of the author's unique construction of US Constitutional theory. While Bennett, Glasner and Travis are concerned about the public's role in the formulation of science policy, Carmen emphasizes instead the rights of scientists to engage in research. This dichotomy expresses the essential tension underlying the DNA

RECENT advances in techniques for the isolation and rejoining of segments of DNA now permit construction of biologically active recombinant DNA molecules in vitro.

There is serious concern that some of these artificial recombinant DNA molecules could prove biologically hazardous. One potential hazard in current experiments derives from the need to use a bacterium like $\mathrm{E}$. coli to clone the recombinant DNA molecules and to amplify their number. E. coli strains commonly reside in the human intestinal tract, and they are capable of exchanging genetic information with other types of bacteria, some of which are pathogenic to man. Thus, new DNA elements introduced into $\mathrm{E}$. coli might possibly become widely disseminated ... with unpredictable effects. ...

Warning shot - extract from the letter from Berg et al., July 1974, recommending the deferral of various types of rDNA experiment.

controversy; namely, the struggle between the self-governance and the social control of science.

In gathering material for The Politics of Uncertainty, the authors were at a considerable disadvantage compared to their counterparts who have studied the corresponding events in the United States. British policy-making essentially took place behind closed doors. In contrast, meetings of the NIH Recombinant DNA Advisory Committee (RAC) were open to the public; moreover, streams of documents, minutes of meetings, internal memoranda and public letters flowed liberally from the committee. Bennett and his colleagues compensated for the lack of a complete published record by relying on interviews with key players in rDNA policy-making, including those involved in the Genetic Manipulation Advisory Group (GMAG). Their book provides a fine-grained analysis of the path towards the formulation of guidelines in Britain and their subsequent relaxation in response to changing perceptions of risk.

At the outset, American and British biologists responded to the 1974 letter from Berg et al. according to the two nations' differing recent histories (the letter, published in both Science and Nature, urged that certain classes of rDNA experiments should be postponed until the risks were better understood). Many American scientists had been sensitized by the debates about atomic weapons and the role of "responsible physics" in a nuclear age, Robert Oppenheimer being the symbol of ambiguity. How can one be true to one's science, true to one's nation and true to one's humanity? When in doubt, which takes precedence? American involvement in Vietnam and the morally dubious roles of science and technology during the war were other factors shaping the consciousness of American scientists. Perhaps going public on gene splicing was the biologists' way of cleansing their consciences and setting themselves apart from the physicists and the chemists. British scientists, on the other hand, faced the rDNA issue in the wake of a widely publicized accident in which two people died after the escape of smallpox virus from a high-containment laboratory at the London School of Hygiene and Tropical Medicine. These backgrounds may explain some of the differences in how the respective political cultures handled rDNA policy-making.

In Britain, organized groups of teachers, civil servants, laboratory personnel and trade unionists were active in the policy process, while in the United States participation came from environmental groups and local communities. Compared to the United States, British rDNA policy was drawn up taking into account diverse interests, but it was all done in greater secrecy. The Politics of Uncertainty highlights differences in the way guidelines were established. British policy-makers sought a loose code, preferring general principles to detailed taxonomies of experiments and viewing the American system of strict guidelines as too inflexible. A canonical framework for assessing the potential risks of recombinant DNA experiments, introduced by Sydney Brenner, was an attempt to bring rationality and order to the taxonomy of cloning. When, in 1979, the approach was brought before the RAC for consideration, it was hastily dismissed. Not only did the committee fail to make sense out of it, but, more significantly, the scheme rated NIH containment levels for certain experiments as too low. Tightening up the rules on containment during a period when the US guidelines were on a fixed course of relaxation was too great a price for a dose of British rationalism.

In comparison to the British way of doing things, the American approach to rDNA regulation is legalistic and processorientated. Typically, this reflects the 
adversarial style of resolving environmental policy debates in the United States, where regulatory discretion is a target for litigation. The British regulatory system is more flexible, and thus, in the case of rDNA, was compatible with the adoption of general prirciples applied by scientific élites.

Notwithstanding these differences, the similarities in outcome were striking. Here were two countries which nourished highly advanced research communities in molecular genetics, which had captured a sizeable share of the Nobel prizes and which faced the prospect that strict regulation of rDNA research might delay the scientific progress of one relative to the other. Out of disparate policy cultures emerged unity of scientific values. The outcome was not coincidental but stemmed from the international and competitive nature of science. Both in Britain and the United States the passage of special legislation was avoided; the guidelines were viewed as an interim measure only, and subject to considerable relaxation; and a multi-tier review process for rDNA research activities was adopted. Even the taxonomies of potential risks varied little.

Overall, The Politics of Uncertainty emerges as the leading study of rDNA policy in Britain. The authors' insights about the blending of science and social process, the interplay of scientist and non-

\section{AIDS Papers from Science, 1982-1985}

\section{Edited by R. Kulstad with an introduction by M. Essex}

108 research papers and reports on acquired immune deficiency syndrome (AIDS) from Science magazine. This fully indexed collection provides essential experimental results and is an excellent source of references to AIDS research worldwide.

\section{5; 653 pages}

Hardcover \$32.95

Softcover $\$ \mathbf{1 9 . 9 5}$

Order from AAAS Marketing, Dept. K, $1333 \mathrm{H}$ Street, NW, Washington, DC 20005. Add $\$ 1.50$ postage and handling.

American Association for the Advancement of Science

\section{IMAGE UNAVAILABLE FOR COPYRIGHT REASONS}

scientist in risk analysis, and, more generally, the process of negotiating the control of research also make it a notable contribution to the broader literature of science policy.

Cloning and the Constitution arrives at a time when discussion about the rights and responsibilities of scientists has intensified. The US Office of Technology Assessment recently published The Regulatory Environment for Science, which examines issues of controls on research, and there are a number of cases where American communities have exercised control over research. On top of the furore over the release of genetically modified bacteria, the city of Cambridge, Massachusetts, recently banned the use of five chemical warfare agents in a testing programme funded by the military, and a farm-worker organization filed a suit against the University of California to stop its research on the mechanization of farming practices.

Carmen's book is made up of three elements: an answer to the question "Is scientific inquiry protected by the Constitution?"; an interpretation of selected periods of the rDNA controversy through a Constitutional perspective; and a report on Carmen's interviews with 52 individuals associated with rDNA research or its regulation. The unifying thread is the author's thesis on scientific inquiry and civil liberties, which is derived from his theory of a living Constitution. Because the US Supreme Court has not decided a case involving the rights of scientists to do research, this thesis is prescriptive only. It can be summarized as follows. Scientific inquiry falls on a continuum; on one end there is pure research, on the other, applied. Both types of research may involve experimentation. Pure research is a form of creative expression and deserves the status of quasi-speech. Once classified as quasi-speech, any research (including experimentation) should be afforded Constitutional guarantees under the First Amendment. To interfere in pure research, the government bears an "extraordinary burden of proof" that it needs to do so. Because much of the early work involving gene splicing was part of basic research, from a Constitutional standpoint federal interference was unjustified.

Under this theory, applied research is treated as conduct or quasi-conduct and, as such, is not guaranteed protection under the First Amendment. For the cases between the extremes, the author suggests a "totality test" to ascertain whether the basic or the applied aspect of the research carries more weight.

Carmen, then, maintains that there is a fundamental right to scientific research (including experimentation) if the research is "pure"; but a rather more useful distinction has been drawn between cognitive/theoretical and experimental inquiry. Under this scheme, scientific work (whether basic or applied) that pertains to generating hypotheses, constructing explanations, propounding theories and the correlative activities of disseminating information, is protected unambiguously as a form of free speech. However, experimental work is a form of action, and it should not make a wit of difference, from the safety and ethical standpoint, whether the experimental programme is basic or applied.

Carmen has constructed a noteworthy thesis but one that I find caught in a web of ambiguity. The dichotomy between pure and applied research is not a sound basis for establishing Constitutional guarantees for science. Curiously, though, this concept has already found a place in the Department of Defense's (DoD) export control regulations on research results, part of a general policy designed to protect the national security and domestic economy of the United States. This goes back to 1984 when the US executive branch issued a draft policy justifying the application of export control regulations to basic research. The policy gave agencies of the government, including $\mathrm{DoD}$, the right to censor any information that "can be used or adapted for use, in the design, production, manufacture, utilization, or reconstruction of articles or materials". In response to vigorous opposition among scientists to post hoc censorship of research results, DoD issued a policy clarification stating that export control regulations will not be applied to fundamental research unless that research has been initially classified. More than any other intervention into the scientific enterprise, national policies restricting the open communication of scientific results are the clearest infringement of civil liberties. Regrettably, these policies escape the critical eye of the author.

Sheldon Krimsky is an Associate Professor in the Department of Urban and Environmental Policy, Tufts University, 97 Talbot Avenue, Medford, Massachusetts 02155, USA, and author of Genetic Alchemy: The Social History of the Recombinant DNA Controversy (MIT Press, 1982). 